\title{
電界放出微小電子源型焦電赤外センサ
}

\begin{tabular}{|c|c|c|}
\hline & 拳彦 & 支術科学大学) \\
\hline & 澤田和 & （豊橋技術科学 \\
\hline & & 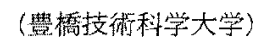 \\
\hline
\end{tabular}

\section{Field Emitter Type Pyroelectric Infrared Sensors}

Katsuhiko Tomita, Non-Member, Kazuaki Sawada, Member, Makoto Ishida, Member

(Dept. Electrical\&Electronic Eng., Toyohashi University of Technology)

A field emitter type pyroelectric infrared sensor was newly proposed. The sensor wasconstructed using field emitter tips, a MOSFET(metal-oxide-semiconductor field effect transistor) and a pyroelectric material. At first, a dependency of the emission current on the infrared incident light intensity was simulated To simulate the emission current, a measurement of the voltage responsibility on the pyroelectric material was carried out. A principle of the new sensor was confirmed by using an equivalent circuit for the infrared sensor, which is composed of discrete devices that are gated cone-shaped field emitters (n-type Si), an n-ch MOSFET and a sheet PZT. From the experiment results, it was found that the proposed device was sensitive to an infrared light of longer wavelength over $10 \mu \mathrm{m}$ and the emission current was proportional to the incident infrared light intensity.The experimental data coincided with simulated ones.

キーワード：赤外線，イメージセンサ，強誘電体，重電体，微小電子源，MOSFE T

1.はじめに

固体赤外センサは当初軍事用途を目的に開発された が、今では日常の自動ドアや侵入警報器などのセキュ リティ分野で確固たる大きな市場を獲得し、安価で高 感度かつ簡便な赤外センサとしてこの 15 年間で身近 なものになった。最近では低温熱源の锶测の重要性が 認識されるに從って省エネや環境対策、そして最近で は交通運輸関連等の民生用謰测機器として近年注目を 集めている。特に高度道路通信システム(ITS)をはじめ とする次世代インテリジェントシステムには不可欠な 要素技術となりつつある。

これまで研究開発されてきた固体赤外センサを大別 すると量子型と型型に分類される。
半導体のバンド構造を利用した量子型センサは，高 感度で応答性が速く，優れた特性を持っている。暗閣 でも物体の形状が認識でき，温度分布の测定も可能な 赤外画像を得ることができるイメージセンサ応用には， 極めて高感度が必要なため、特に量子型が使われてき た。しかし量子型は狭いバンドギャップを持つ半丵体 を使用するため、低温に椧却する必要性があり、大型 で高侱な装置となる。さらに感度の波長依存性などの 制限があり，民生デバイスとして报いにくいのが現状 である。

これに対して，機能材料の赤外線吸收に伴う温度変 化による物性值の変化を検知する熱型赤外センサは， 室温で動作させることが可能であり，一般的に取り扱 いやすい。しかしながら，量子幣のセンサに比べて一 
析以上感度が低く，高感度化が課題となつている。

熱型には、焦電型、ボロメ一夕型、熱電推型等があ り、それそれ固有の特街を持っている。特に強誘電体 材料定応用する焦電型赤外光娭出は，チョッビング機 構を必要とするものの，ボロ一夕型や熱電堆型の赤 外光検出に比べ感度が高く，外乱の熱雑音の影管を受 けにくく，さらに熱型特有の室温動作が可能であると いう優れた特徵を持っている。

一般に熱型赤外センサの熱容董は感度、応答速度に 直結するため、その高感度化には、热容量の制御が非 常に重要となる。特に熱型赤外イメージセンサは 2 次 元配列が不可久のため、微小な加工技術が必要となる。 最近半導体ブロセス技術を応用した微細加工技術によ り、熱型センサの 3 次元構造体を加土するシリコンマ イクロマシニング技術の発展の恩惠を受けて、小型で 安洒、更に常温動作の赤外イメージンサが実現でき るようになってきた。(1,2,3)

ところで光電子放出面は、光計测、微弱光イメージ ング等に用いられる。なぜなら光電子放出面から放出 された光強度に見合った電子は、2 次電子増倍管やマ ルチチャンネルプレート（MCP）により、極めて低 雑音で、增倍が可能であるためである。しかしながら 光電放出面には、2つの技術課題を抱えている。その 1つは、外部光電效果を利用しているため，その受光 可能な波長は原理上，長波長領域まで延ばすことは困 難であることにある。近赤外領域で感度を持つ光電子 放出面 [A I/InP/In GaAs/InP(Sub.)]に おいても超格子構造を導入することで受光可能な波長 領域を $1.7 \mu \mathrm{m}$ 程度までのばすことができたと報告 されている。 ${ }^{(4)}$ 半導体村料による光電面の赤外波長特 性は2 $2 \mathrm{~m}$ 程度が限界と考えられているが、さらにこ の波長に対する十分な量子効率を得るにはなおさら厳 しい状況となろう。

もう一つの技術課題は、上述の [A I / I n P / I n G a As/InP(Sub.) ]光電面を持つPMTにおいても， その量子効率は $1.6 \mu \mathrm{m}$ の波長で最大 $0.1 \%$ 以下と 非常に小さいことである。光電子放出䩂からの出力電 子は，2次電子增倍管やマルチチャネルプレートを用 いて，低雑音で 10 万倍以上に增幅できる。しかし2 次觶子增倍管を用いてその信寻を 10 万倍以上に低雑 意で增幅できても，先に述へたように1次量子效率が 低いため，得られる画像のS／N比が悪くなる。

ここで今までの赤外センサを固体型と電子放出型に 分類すると、表 1 に示すようになる。
表 1 赤外センサ

Table 1. Infrared sensors

\begin{tabular}{|c|c|c|c|}
\hline & & 固体型 & 電子放出型 \\
\hline 量子梨 & 半道体 & PbSe, InSb, SiPt ${ }^{(5)}$ & 光電村料 \\
\hline & & $\mathrm{HgCdTe}$ & $\mathrm{Al} / \mathrm{In}_{\mathrm{n}} \mathrm{P} / \mathrm{InGaA}_{\mathrm{s}} / \mathrm{I}_{\mathrm{n}} \mathrm{P}($ Sub. $)$ \\
\hline 繁型 & $\begin{array}{c}\text { 焦電型 } \\
\text { ボロメータ } \\
\text { 熱電婎型 }\end{array}$ & $\begin{array}{l}\text { PZT など搏誘電体材 } \\
\text { 料 } \\
\text { 酸化物林料 } \\
\text { Sb-Bi 系、Si-AI 系等 }\end{array}$ & 敨当なし \\
\hline
\end{tabular}

この表から明らかなように今まで熱型センサで電子放 出型の高感度センサに現在該当するものがない。

今回の報告では，近年進展著しい電果放出微小電子 源 ${ }^{(6,7,8)}$ 孛用いて、従来の光電子放出面では原理上受光 不可能であった $3 \mu \mathrm{m}$ 以上の赤外光を受炕可能にし、 さらに感度の高い赤外イメージセンサの寒見を目指し た基䃈的な実験結果を述べる。

\section{2. 電界放出微小電子源型焦電赤外センサの提案}

まず我々は，電界放出微小電子源型焦電赤外センサ として，MOSFETのドレイン領域に三極管構造の 電界放出微小電子源を設け，ゲート領域には焦電体を 配置するデバイス構造を提案している。

焦電型センサは赤外光の入射によって生じる温度上 昇に基つく自発分極値の変化により，焦電体表面の電 荷量が変化し，その雨端に赤外光の入射光量に依存し た電生が発生する。今回提案している電界放出微小電 子源型焦電赤外セン开の原理は，その焦電体の発生電 圧をMOSFETのゲートに加えてMOSFETの千 ヤネル電流を制御することにある。またシリコン微小 電子源加らの放出電流を制御，安定化させる方法とし て, MOSFETのドレインに微小電子源を配して, MOS F E Tのゲート電極で放出電流る制御する方法 が提案されている(9)。この方法はシリコン微小電子源 を集積回路技術と融合活用できる手法の一つであると 考光られている。そこで赤外エネルギ一を受けた焦電 体からの信号をMOS F E T ゲート部で受けて、その ドレイン出力をドレイン領域に設けた微小電子源から のエミッション電流として梭知する新しい動作原理の 赤外センサを提案している。今回提案のデバイス棈成 により、焦電体に入射する赤外線光量に依存した焦電 
体誘起電荷量に比例した量の電子がドレインにある電 界放出型微小電子源から放出可能となる。図 1 に提案 するデバイス概念図を示す。

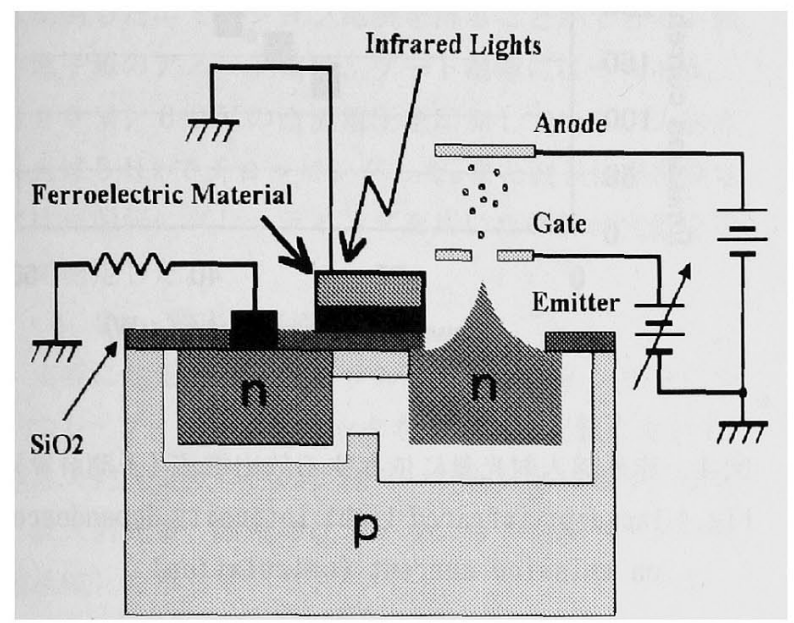

図 1 光センサ型フィールドエミッ夕方式ピクセル 構造の提案

Fig.1 A pixel structure of a proposed photosensitive field emitter.

\section{3. 本提案デバイスの放出電流值の概算予测}

上記提案の新しいデバイス動作原理を確認するため、 最初に一般的な焦電型センサの感度を測定し、更に初 段入力 F E Tおよびソースフォロア回路から赤外線入 射光量に依存するシリコン・フィールドエミッタに流 れるドレイン電流及びピクセル構造（図 1 ）での放出 されるエミッション電流の概算予測計算を試みる。次 に害際に焦電体とMOS F E T およびシリコン・フィ

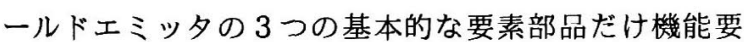
素部品でディスクリート回路を作製し、入射赤外線エ ネルギーに相関すると考えられるエミッション電流を 計测する。最後に先の概算予测放出電流值と実测放出 電流值を比較検討する。

\section{〈3.1〉エミッション電流值の概算}

市肘されているセンサは、初段回路にJ F E T や M O S F E Tを使用し、更にソースフォロア回路を介し て外部に信号を取り出す構成としている。この市販セ ンサでは、実際には赤外線入射で焦電体の両端で発生 した電圧が F E Tのソースフォロア回路出力として変 換されても、初段 F E T のドレイン電流值そのものは 直接計測できない。そこで今回は概算的な計算で動作 原理を確認する目的で、理想的なソースフォロア回路
として相互コンダクタンス $\left(\mathrm{g}_{\mathrm{m}}\right)$ を 1 と見なし、ソー スフォロア回路で F E Tソース側に接続されている抵 抗 Rs $(10 \mathrm{~K} \Omega)$ に流れる電流をドレイン電流とした。 今回提案しているピクセル構造では、F E Tに流れ るドレイン電流をエミッション電流として計測するも のである。(図1, 図 5 参照)このドレイン電流は、焦 電体誘起電荷量に変調されたゲート電圧に比例してい ると仮定できる。従ってエミッション電流は、焦電体 誘起電荷に変調される。以上の仮定により、以下の手 法を用いて、エミッション電流を予測した。 焦電型センサでは一般に入射エネルギーを計算でき る黒体炉などの光源を使用し、センサ感度の性能指数 の 1 つとして電压感度 $(V / W)$ がよく用いられる。 次にこの電圧感度からエミッション電流の計算式を示 す。

$$
\mathrm{I}_{\text {enission }}=\mathrm{I}_{D}=\mathrm{R} \times\left(\mathrm{W}_{0} \times \mathrm{A}\right) / \mathrm{R}_{\mathrm{S}} \cdots
$$

$\mathrm{W}_{0}$ : 光源光量 $\left(\mathrm{W} / \mathrm{cm}^{2}\right)$

$A$ : 焦電体面積 $\left(\mathrm{cm}^{2}\right)$

$\mathrm{R}$ : レスポンシブティ $(\mathrm{V} / \mathrm{W})$

$\mathrm{V}: \mathrm{F}$ E T ゲート入力に発生する電位 (V)

$\mathrm{R}_{\mathrm{s}}$ : ソースフォロア回路のソース側抵抗 (10K $\Omega$ )

$\mathrm{I}_{\mathrm{D}}$ : ソースフォロア回路で抵抗 $\mathrm{R}_{\mathrm{S}}$ に流れる電流

$I_{\text {emission }}$ : フィールドエミッタから放出される電流 量 (A)

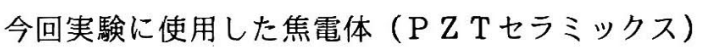
の焦電特性関連の物性值を表 2 に示す。また最初の予 測計算に必要焦な電圧感度の測定や後のシリコン・フ

\begin{tabular}{|c|c|}
\hline 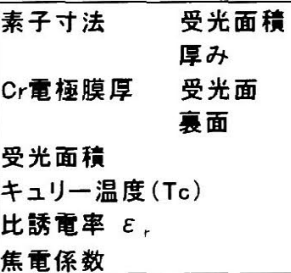 & $\begin{array}{c}2 \times 0.8\left[\mathrm{~mm}^{2}\right] \\
0.1[\mathrm{~mm}] \\
80 \pm 20[\AA] \\
1000[\AA] \\
1.6 \times 10^{-2}\left[\mathrm{~cm}^{2}\right] \\
330\left[{ }^{\circ} \mathrm{C}\right] \\
325 \\
4 \times 10^{-8}\left[\text { Coul. } / \mathrm{K} / \mathrm{cm}^{2}\right]\end{array}$ \\
\hline
\end{tabular}

表 2 P Z Tセラミックスの諸特性

Table 2. Properties of PZT ceramics

イールドエミッタとの組み合わせ実験にも同じ焦電体 を使用したので、その焦電体の寸法、受光面積なども 示す。

焦電型センサは出力信号を得るため、黒体炉の放射 
前に赤外線入射を断続するチョッバーが必要であり、 チョッピング周波数を $5 \mathrm{~Hz}$ の条件で統一した。焦電型 センサの電圧感度を測定するシステムを図 2 に示す。

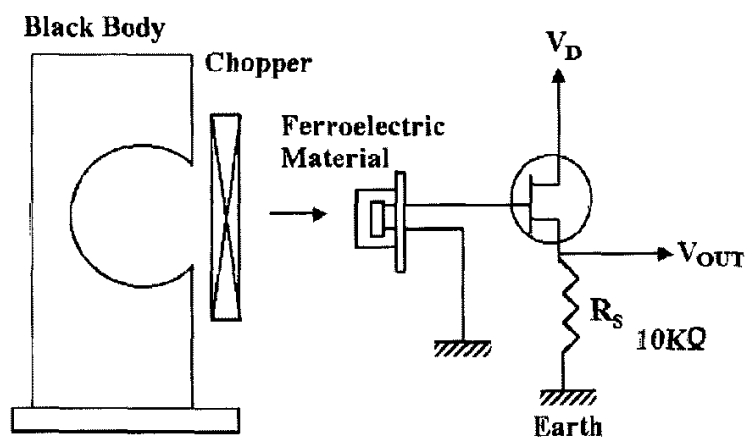

罒 2 感度測定システム

Fig.2 Schematic diagram of infrared sensor measurement.

予測計算の基本となる焦電型赤外センサの電王感度 を測定した。図 3 にチョッピング周波数に依存する電 圧感度を示す。予測值計算には、 $5 \mathrm{~Hz}$ での平均的数 值 $(50 \mathrm{~V} / \mathrm{W})$ を採用した。

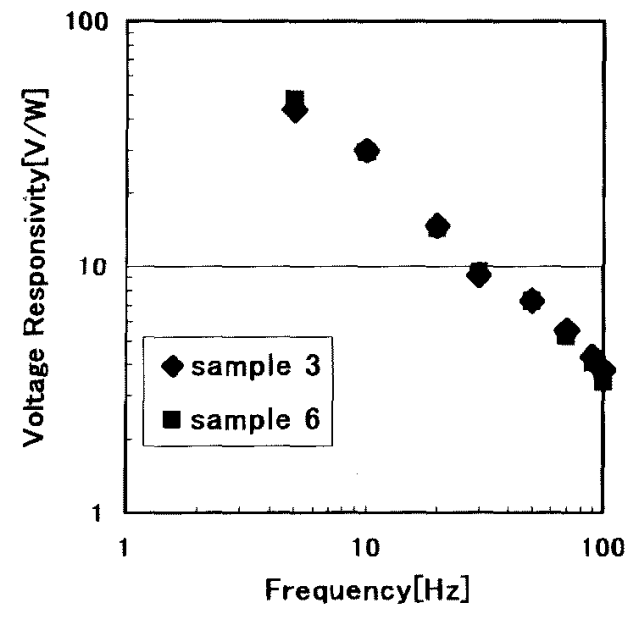

図 3 電圧感度の周波数依存性

Fig.3 Frequency dependence of the voltage responsivities at various pyroelectric elements.

\section{〈3.2〉予测計算結果と考察}

図 4 に上記電压感度の测定結果を使用し、式（1） による入射光量に依存する電子放出による電流值の予 测計算結果を示す。約 $50 \mu \mathrm{W}$ の射エネルギーにお いて約 $270 \mathrm{nAの}$ 放出電流值となった。

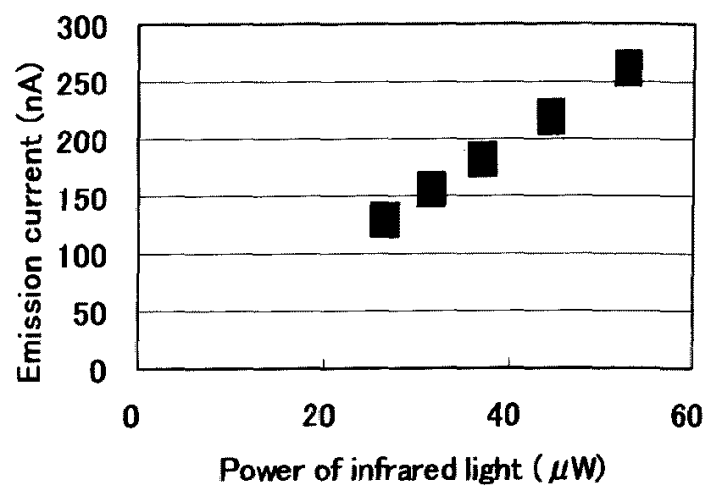

図 4 赤外線入射光量に依存する放出電流 (予測計算) Fig. 4 Incident infrared light intensity dependence on emission current (calculation).

\section{4.ティスクリート構成による原理確認実験}

\section{$\langle 4.1\rangle$ 実験方法}

次に3つの基本的な要素部品の組み合わせによる実 際の原理動作確認実験を行った。シリコン・フィール ドエミッ夕は、先端の曲率半径が $40 \mathrm{~nm}$ となる 3 極

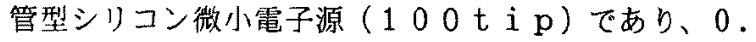

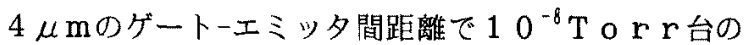
真空装置内に配置した。結合した微小電子源は真空装 置の外部に配置してあるn-MOS F E T のドレイン 側に接続されている。MOSFETのゲート部には， 赤外光受光部として P Z T の焦電体を配置した。

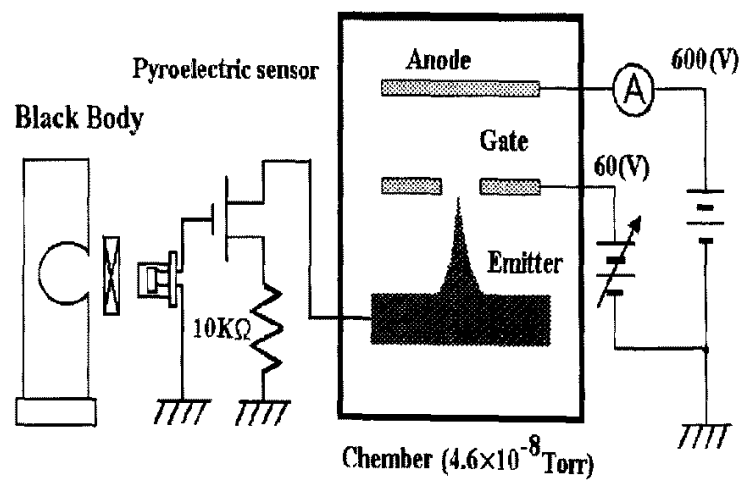

図 5 原理確認用実験装置

Fig.5 Experimental setup.

図 5 に示すような構成を用いて実鈳を行った。回路 構成はドレインに直列にシリコン・フィールドエミッ 
夕を接続し、FE Tソース側は抵抗（10 K $\Omega ）$ を接 続したのちに接地している。赤外線の入射により焦電 体の誘起電荷量が変調され、MOS F E Tゲート電圧 に比例したエミッション電流を得ることができる。微 小電子源のアノード電極, ゲート電極にはそれそれ， $600 \mathrm{~V}, 60 \mathrm{~V}$ の直流電圧を印加している。入射赤 外光は $5 \mathrm{~Hz}$ でチョッビングした。また波長依存性測定 では光源側にグレーティングを用いた赤外分光器を用 いて測定した。

\section{〈4.2〉放出電流測定結果}

実際に焦電型赤外センサの F E Tドレイン部分にシ リコン・フィールドェミッ夕を接続した実験において、 赤外入射光量依存性の実測デー夕を図 6 に示す。横軸 には入射光量，縦軸にはエミッション電流（アノード 電流值）を示している。

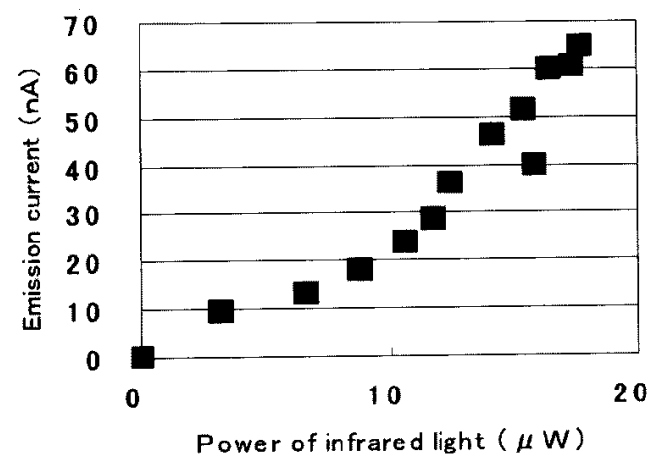

図 6 赤外線入射光量依存性（実測データ）

Fig.6 Incident light intensity dependence on emission current.

電子放出電流值の実測結果は、約 $20 \mu \mathrm{W}$ 入入射工 ネルギーにおいては約 $65 \mathrm{n} \mathrm{A}$ の放出電流值となった。 赤外入射エネルギーの約 $10 \mathrm{n}$ A 以下の微少電流範囲 で放射電流值のバラッキが多く、ノイズレベルと見な している。

フィールドエミッタから放射するエミッション電流 值において、概算予測值と実測值を比較するため、図 7 にその結果をまとめた。

放射電流の実験及び計算結果（図 5，6）の比較を すると、同じ入射エネルギー条件でのデータは得られ なかったが、エネルギー放射による電子放出は、線形 特性であり、オフセット電压を持っていると考えられ る。このオフセット電圧は、実験に使用したＭＳ下 ランジスタが、エンハンスモードであることに起因し ているためである。デブレッションモードを用いれば，

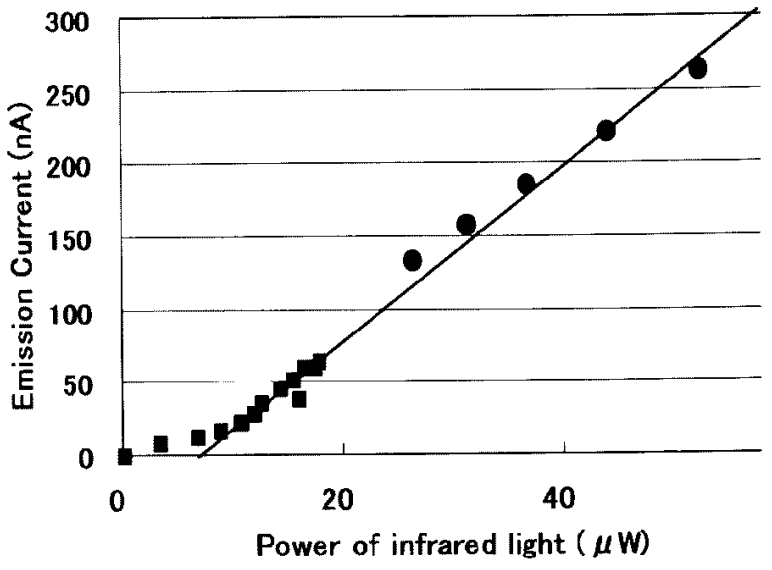

- Experimantal 0 Calculation

図 7 放射電流の実験及び計算結果の比較

Fig. 7 Comparison of emission current between experimental and calculated data.

このオフセットをなくすことが出来る。

従来の光電子放出面では原理上検出不可能であった 波長 $3 \mu \mathrm{m}$ 以上の赤外光に対する感度が、電界放出微 小電子源型焦電赤外センサでは、波長 $4 \mu \mathrm{m}$ から 10 $\mu \mathrm{m}$ 範囲において波長依存性がないことが確認でき た。図 8 に、電界放出微小電子源型焦電型センサの赤 外線入射光波長による感度依存性を調べた結果を示す。

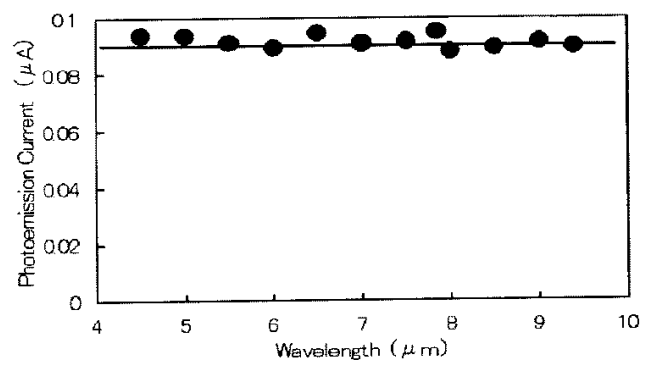

図 8 放出電流の入射赤外光波長低存性

Fig. 8 Incident light wavelength dependencies on emission current.

\section{5.まとめ}

シリコン微小電子源，MOSFEＴおよび焦電型セ ンサを組み合わせた, 新しい電界放出微小電子源型焦 電赤外センサの提案を行った。まず提案したデバイス 動作原理の確認のため、赤外線入射光量に依存するシ リコン・フィールドエミッタに流れるドレイン電流值、 
及びピクセル構造での放出エミッション電流の概算予 測計算を試みた。次に実際に焦電体とMOSFETお よびシリコン・フィールドェミッ夕の3つの基本的な 要素部品からなるディスクリート回路でエミッション 電流值を計测した。その結果，当初に電圧感度測定か ら求めた概算放出電流值と、焦電体と初段 MO S F E Tのドレイン側に直列にシリコン・フィールドエミッ タを設けたディスクリート回路において、オフセット 電圧はあるが、実測放出電流值は、赤外入射エネルギ 一に線形応答を示す。更に従来の光電子放出面では原 理上検出不可能であった波長 $3 \mu \mathrm{m}$ 以上の赤外光に対 する感度が電界放出微小電子源型焦電赤外センサでは、 10 ミクロン帯にまで及ぶことが確かめられた。これ ら比較検討の結果、本提案デバイスの動作原理が正し いことを確かめることができた。この結果は上記 $3 つ$ の機能を一体化したデバイスは、微小電子源型焦電赤 外センサとして実現可能であることを示唆していると 考えられる。

今回の基礎実験は, 単体の赤外センサでの原理確認 の実験で留まっているが、現在 2 次化赤外センサの実 験を進めている。非泠却型である焦電型固体センサか ら得た赤外 2 次元情報を微小電子源から 2 次元電子分 布として出力できると, 従来の 2 次電子増倍管または マルチチャネルプレート、あるいはマイクロマシン技 術の異方性エッチング技術を駆使した超小型のマルチ チャネルプレート ${ }^{(10)}$ と組み合わせることにより、出力 電子を低雑音で増幅できる。赤外エネルギーを電子に 放出させる変換効率が高い時には、従来の熱型センサ の 10 - 1000 倍の高感度赤外イメージが可能にな るものと期待している。

\section{謝辞}

本デバイスの試作および評価にあたって、堀場製作 所・高田秀次氏、岡本一隆氏、冨永浩二氏、豊橋技術 科学大学・高室大介氏のご指導、ご協力を頂きました。 深く感謝いたします。

(平成 12 年 6 月 5 日受付, 同 12 年 10 月 12 日再受付)

\section{文献}

1) M.H.Unewisse, et a1. : Proc.SPIE.2269(1994)43

2) H.Beratan, et al. : Proc.SPIE.2274(1994)147

3 ) A.Tanaka, et a1. : IEEE Trans. Electron Device ED-43 (1996) 1894

4) 新垣実, 廣畑徹, 鈴木智子, 菅博文, 書馬輝夫 :
テレビジョン学会技報，20（30），19(1996）

5 ）木股雅章, et al.：日本赤外線学会誌, 5,1(1995)3 3-42

6) C.A.Spindt, et al.: IEEE Trans. Electron Devices, 36 (1988) 225.

7 ) H.F.Gray, et al. :Technical Digest of IEDM, (1986) 776.

8 ) K. Sawada, et al. : IEEE Trans. Electron Devices, $45[1], 321-325$

9 ) K.Koga, S.Kanemaru, T.Matsukawa, J. Itoh:J. Vac. Sci \& Tech. B17(2), 588 (1999).

10) K. Takahashi, H. Sasaki: Technical Digest of $16^{\text {th }}$ Sensor Symposium, 203 (1998).

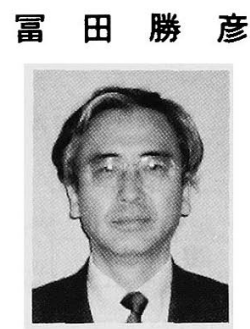

（非会員）1962 年立命館大学理 工学部化学科卒業。1962 年堀場 製作所入社.1999 年豊橋技術科 学大学大学院博士後期課程。主 として赤外センサ、イオンセン サ等各種のセンサ研究及び応 用製品開発に従事。

澤 田 和 明 （正員）1991 年豊橋技術科学大

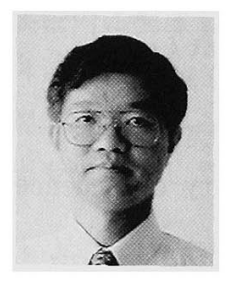
学大学院博士後期課程終了。 1991 年静岡大学電子工学研究 助手。1998 年豊橋技術科学大学 講師。主としてイメージセンサ の高感度化に関する研究に従 事。工学博土。

石田 誠 （正員）1979 年京都大学大学院博 土後期課程修了。1979 年豊橋 技術科学大学助手。1991 1992 年ベルギー王国ＩＭＥＣ 客員教授、S O I 構造の形成 とセンサ・集積回路技術への 応用についての研究に従事。 工学博士。 